\title{
Structural and Tectonic Interpretations from Airborne Magnetic and Landsat ETM Data: A Case Study of Yola Arm of the Upper Benue Trough, Nigeria
}

\author{
Emberga, T.T ${ }^{2}$ Opara, A.I ${ }^{1}$, Onyekuru S.O ${ }^{1}$, Selemo A ${ }^{1}$. \\ ${ }^{1}$ Department of Geosciences, Federal University Of Technology Owerri \\ ${ }^{2}$ Department of Physics/Electronics, Federal Polytechnic, Nekede -Owerri
}

\begin{abstract}
Structural and tectonic interpretation of the Yola arm of the Upper Benue Trough using the airborne magnetic and Lansat ETM data was carried out to interpret geological features of the Yola arm of the Benue Trough and to infer their relationship with basin architecture, morphology and dynamics, thereby presenting a better understanding of the geology. This work is aimed to determine the magnetic basement depth, establish the basement topography and relief to determine the structural and tectonic features associated with the basin and to infer the effect of such structures on basin geodynamics. The residual data was subdivided into 24 spectral blocks using OASIS MONTAJ software program. Two prominent magnetic depth source layers were identified. The deeper source depth values obtained ranges from $1.56 \mathrm{~km}$ to $2.92 \mathrm{~km}$ with an average depth of $2.37 \mathrm{~km}$ as the magnetic basement depth while for the shallower sources, the depth values ranges from $-1.17 \mathrm{~km}$ to $0.98 \mathrm{~km}$ with an average depth of $0.55 \mathrm{~km}$. The shallow depth source is attributed to the volcanic rocks that intruded the sedimentary formation and this could possibly be responsible for the mineralization found in parts of the study area. Data enhancement was carried out to delineate residual features relative to the strong regional gradients and the more intense anomalies due to basement features, igneous intrusive, etc. Typical techniques applied were computation of reduction to pole, trend surface analysis, upward continuation, etc. The detail in the total magnetic field data supplemented by the range of enhanced maps and images provided the basis for qualitative interpretations in which geological boundaries, lithologies and structural features were delineated. Several lineaments with dominant trends of $\mathrm{N}-\mathrm{S}$ and $\mathrm{NE}-\mathrm{SW}$ directions were revealed in the study area. From the economic point of view, the basement depth in the Upper Benue Trough proper and the series of tectonic events associated with the basin do not favour the accumulation and entrapment of hydrocarbons. However, mineral ores are believed to be prevalent in the study area.
\end{abstract}

Keywords: Magnetic basement, Tectonics, basement depth, shallow depth and structural

\section{Introduction}

The Benue Trough is a linear NE-SW trending rift system whose development was closely associated with the separation of Africa from South America and the opening of the South Atlantic Ocean during the Cretaceous. The origin and evolution of the Benue Trough are fairly well documented (Wright (1968), Burke et. al 1971, Nwachukwu 1972, Olade 1975, Benkhelil 1988, 1989). The Benue Trough is characterized by the occurrence of several minerals of economic importance ranging from Coal, Barytes, Lead and Zinc etc. The aeromagnetic data for this work were acquired from the Geological Survey of Nigeria. The present area of study is the Yola arm of the Upper Benue Trough. The determination of sediment thickness above the basement and the delineation of major structures are very essential for better understanding of the geology of the Yola arm of the Upper Benue Trough. This work presents the results of the analysis of aeromagnetic data over this area.

The objectives of the study are to identify and delineate the structures associated with the area and also the trends/patterns of such structures and infer their relationship with groundwater assessment

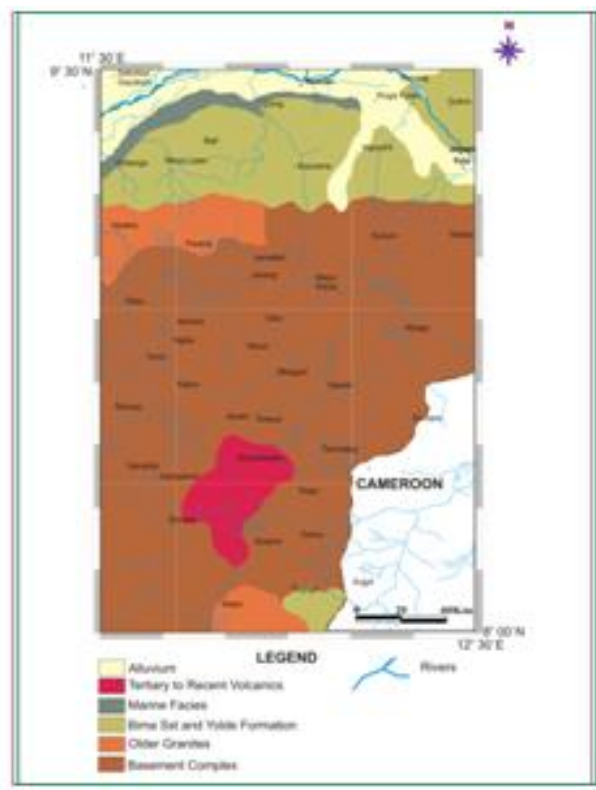

Figure 1: Geology map of the study area

\section{Geology of the Study Area}

The study area is located within the Upper Benue Trough. Benue Trough is defined as an intercontinental Cretaceous basin about $1000 \mathrm{~km}$ in length stretching in a NE-SW direction and resting unconformably upon the Pre- Cambrian 


\section{International Journal of Science and Research (IJSR) \\ ISSN (Online): 2319-7064}

Index Copernicus Value (2013): 6.14 | Impact Factor (2014): 5.611

Basement. In the Yola, the oldest sediments belong to the Bima sandstone and Yolde Formation which outcrop in the major part of the study area Eze Aku Shale Group and Yola Formation are also present in the study area. The Bima Sandstone and Yolde Formation are variable sequence of sandstones and shale which mark the transition from Continental to Marine sedimentation. The Upper part of the formation (Bima sandstone and Yolde) contain blue-black shales (Carter et al ,1963). From the map of the study area (Fig. 2), it is observed that on the southern part of the area, the basement complex outcrops on the surface. The basement rocks are mainly quartz, feldspathic, biotite, hornblende, gneisses, quartzites, marbles and calc-silicate rocks.

\section{Materials and Method}

The data used for the study were compiled using the geological map of the study area comprising Numan (sheet 196), Dong (sheet 195), Jada (sheet 217) ,Kiri (sheet 237), Monkin (sheet 216) and Toungo (sheet 236), each at a scale of $1: 100,000$ and satellite image - Landsat 5 TM,

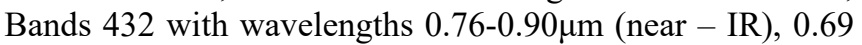
$\mu \mathrm{m}$ (Red) and $0.52-0.60 \mu \mathrm{m}$ (green). It has high spatial resolution of $30 \mathrm{mx} 30 \mathrm{~m}$ ground area. A subset of the satellite data covering the study area was created using Erdas image processing software. A high speed large memory digital electronic PC with a coloured printer and plotters for map printing as well as a colour monitor for visualization of image were used. A table scanner was used to scan all the relevant maps used for the study.

Erdas imaging was used for subsetting the study area from available satellite data. Integrated Land and Water Information System (ILWIS) was used for creating several themes or layers from the satellite image. This software has the capabilities for various image enhancement techniques such as linear enhancement, statistical analysis, principal component analysis and normalized difference vegetation index. The following image analysis techniques were carried out. Linear (edges) Enhancement: This was carried out to improve the contrast quality of the image to aid better visual interpretation.

Filtering - (High pass filtering): A local contrast enhancement method for the purpose of highlighting linear features or edges - faults, fractures and joints, drainage patterns, and geological boundaries. Filtering is a way of separating signals of different wavelength to isolate and hence enhances any anomalous feature with a certain wavelength. A rule of thumb is that the wavelength of an anomaly divided by three or four is approximately equal to the depth at which the body producing the anomaly is buried. Thus filtering can be used to enhance anomalies produced by features in a given depth range. Traditional filtering can be either low pass (Regional) or high pass (Residual). Thus the technique is sometimes referred to as Regional-Residual Separation. Bandpass filtering isolates wavelengths between user-defined upper and lower cut-off limits.

Normalized Difference Vegetation Index (NDVI): This is a pixel transformation technique that was carried out to highlight areas where the green activity of chlorophyll (i.e. green plants) is dominant in the image using the NDVI Algorithm, which is given by NDVI landsat - TM3 TM4/TM3-TM4. TM3 - Is the red region of the wavelength band of the electromagnetic radiation.TM4 - Is the near infrared region of the wavelength band of the electromagnetic radiation. Highlighting areas where green plants are dominant is a pointer to groundwater occurrence.

Digital Data Base Creation: On -screen digitization was carried out on the Landsat image. Different layers or themes were created. The following layers among others were created using ILWIS: -lineament and drainage maps. Also from the existing topographic map, drainage pattern and linears are generated. The aeromagnetic data were generated by digitizing the maps at grid-contour intercepts. These data were Processed with Surpher 8. Sixteen (24) spectral blocks were created as shown in Table 1below. The data were modeled to get the basement depth contour map of the study area. Also the first to fourth degree regional magnetic field as well as the first to fourth degree residual (polynomial) magnetic field map of the study area was generated.

\section{Interpretations of Results}

Various visual interpretation of the satellite image was carried out after the pictorial quality of the image was improved through linear enhancement and filtering of the image. The drainage of the area is easily visible in the landsat TM image. The drainage pattern was digitized onscreen as segment map using ILWIS. The drainage linears of the area was also produced from existing topographic map Numan, Dong, Jada, Kiri, Monkin, and Toungo. The drainage pattern is dendritic which is indicative of lithological, structural, and topographic differences. It is also indicative of alluvial rocks, which is typical of the geology of the area that consists mainly of sedimentary rocks. The drainage texture of the area is variable (coarse to fine). It is characteristic of sedimentary rock and variable permeable soil material, such as the alluvium and Bima/Yolde Formation. The direction of flow of surface water can be seen on the image too. The flow directions are northwest and north south directions controlled by topography and geological structures. This flow direction no doubt influences the hydrographic network of groundwater in the area.

Digital image processing technique was carried out to highlight areas in the image where vegetations/green plants are more active. Two major classes of objects in the shades of gray in the landsat image are light tone and dark tone. The very light tone areas are areas where vegetation occur and the light - dark tone areas represent rock out crops/bare surfaces, and very dark tone represent water bodies. 


\section{International Journal of Science and Research (IJSR) \\ ISSN (Online): 2319-7064}

Index Copernicus Value (2013): 6.14 | Impact Factor (2014): 5.611

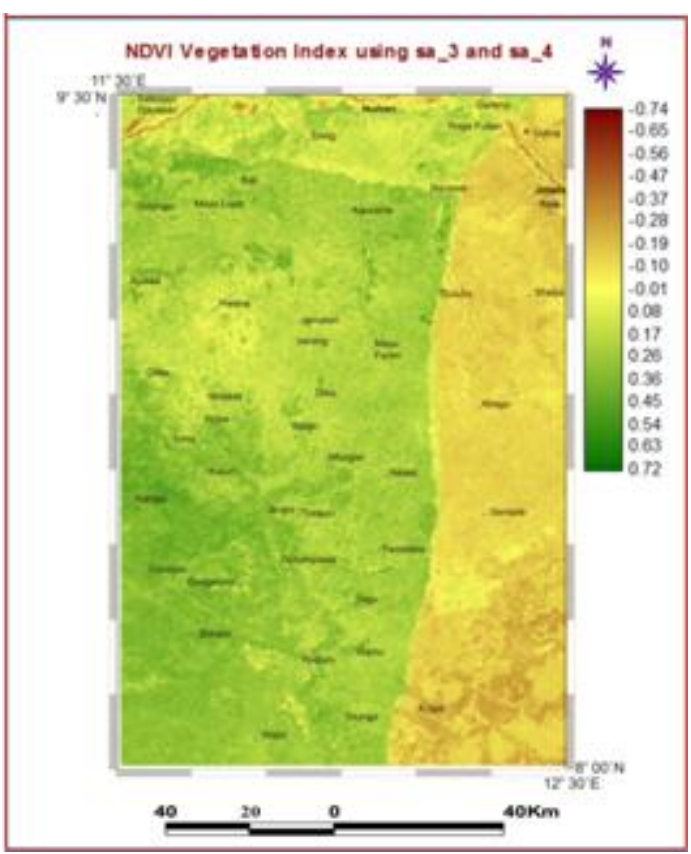

Figure 2: Normalized difference vegetation index (NDVI) Map

Simple digital image processing techniques were applied on the image to enhance the edges or linear features. This was followed by computer aided visual interpretation of lineaments. The result of the lineament analysis shows that numerous fractures and lineation occur at the northeastern and northwestern sides of the satellite image. The common orientations of the lineaments are NE-SW and NW-SE. A dolerite dyke related to a major NE-SW striking fracture occurs in NW of the study area.

The drainage linear was derived from the drainage pattern of existing topographic map and the satellite image. This is to correlate the trends of drainage and structural orientation in the whole area to establish whether the drainage is structurally controlled. The result of the statistical analysis of the drainage linear and visual observation of it indicates that the drainage follow weak parts in the earth such as fractures and faults. Visual interpretation of lineaments was complemented by some simple digital image processing techniques that highlight linear features. A good technique that was used is the directional edge enhancement and convolution filtering. These techniques will make conspicuous all linear features and boundaries seen on the image.

Apart from man-made structures, the result shows that the area has numerous linear features, which include drainage channels, fractures and joints. The Rose diagram (azimuth distribution diagram): The strikes and lengths of all lineaments were measured and computed to obtain the rose diagram (Fig.6). The important structural trends are NE-SW, $\mathrm{N}-\mathrm{S}$ and $\mathrm{E}-\mathrm{W}$.

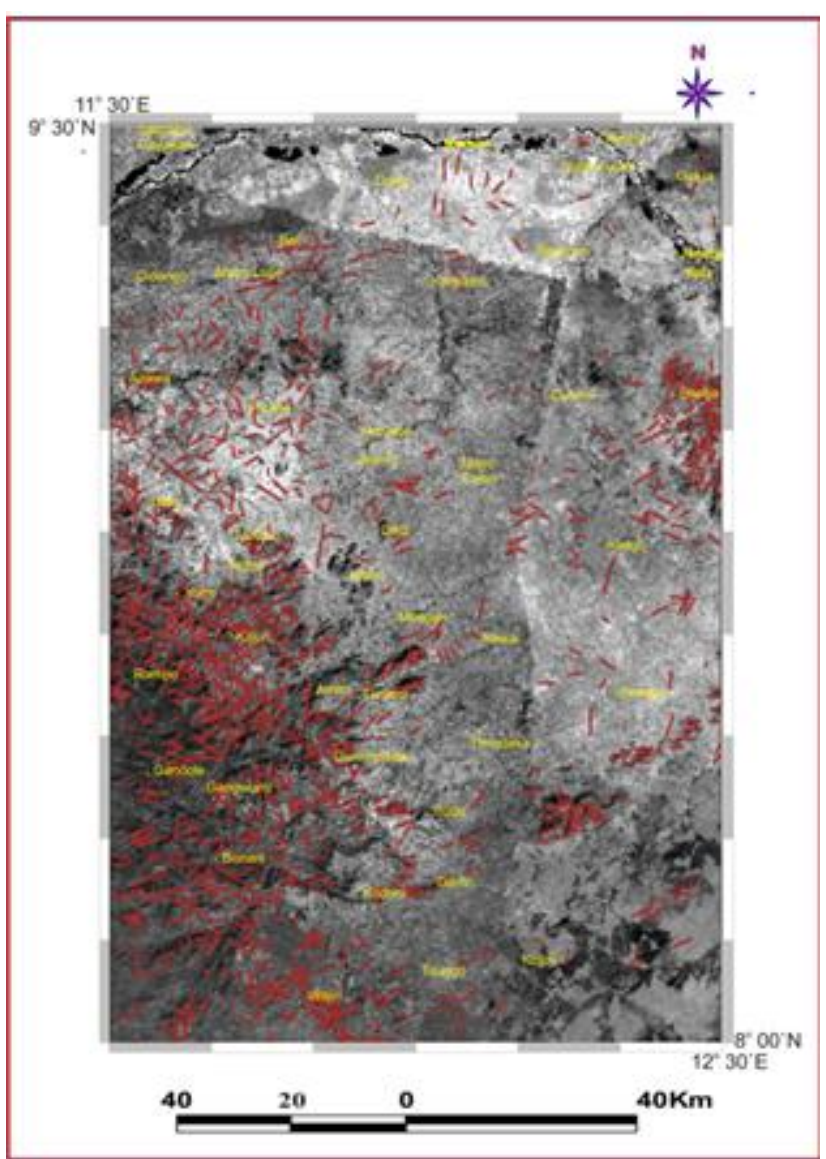

Figure 3: Lineament on Edge Enhanced Band 5

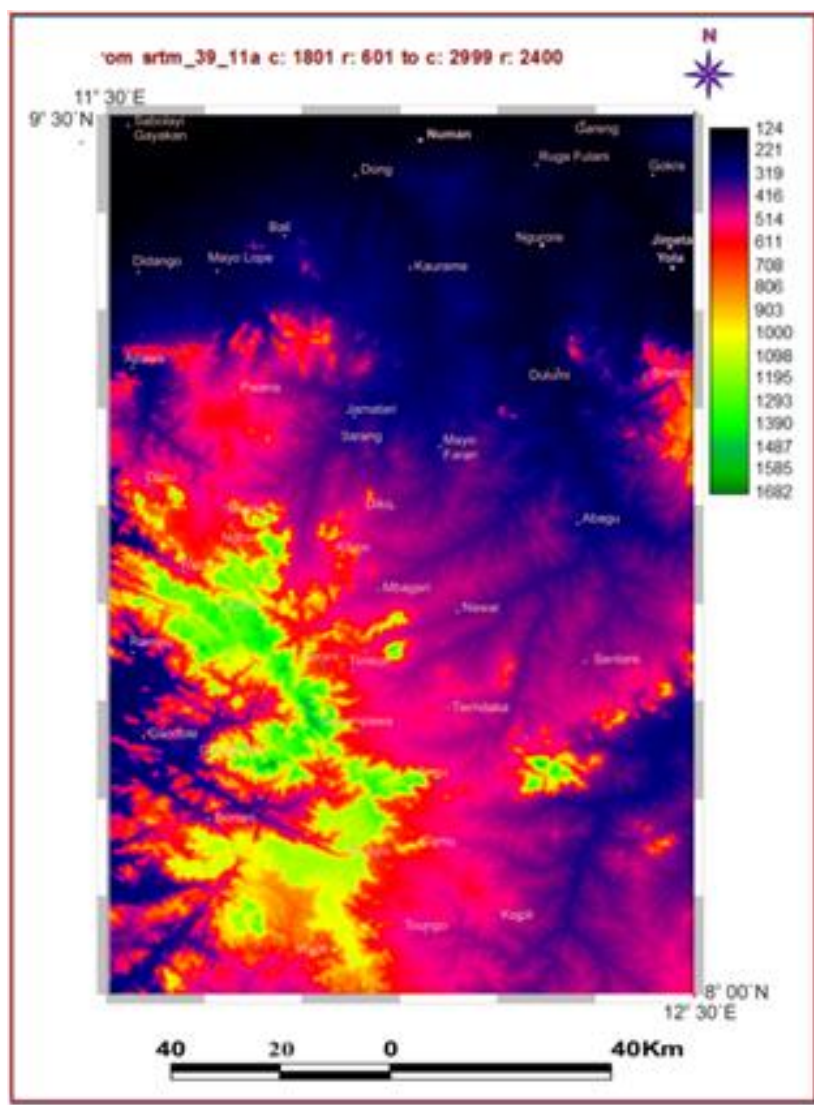

Figure 4: Digital elevation model (DEM) 
International Journal of Science and Research (IJSR)

ISSN (Online): 2319-7064

Index Copernicus Value (2013): 6.14 | Impact Factor (2014): 5.611

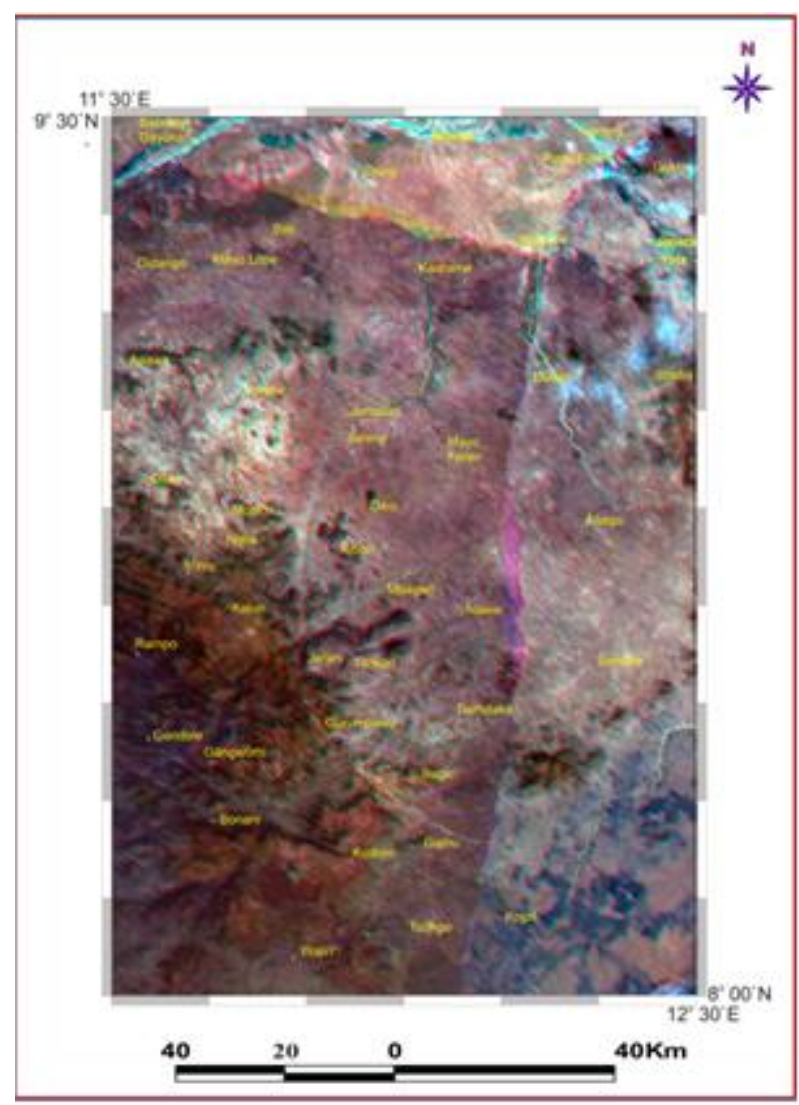

Figure 5: False colour composite map

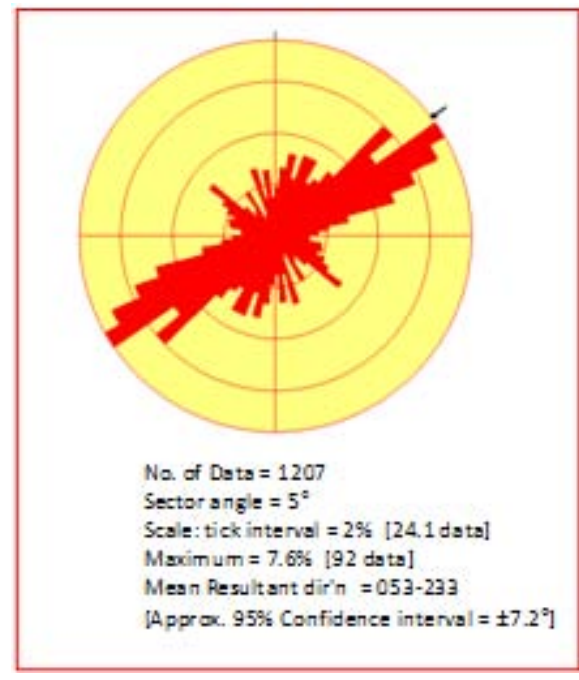

Rose Digram for upper Benue Trough

Figure 6: Rose diagram of upper Benue Trough

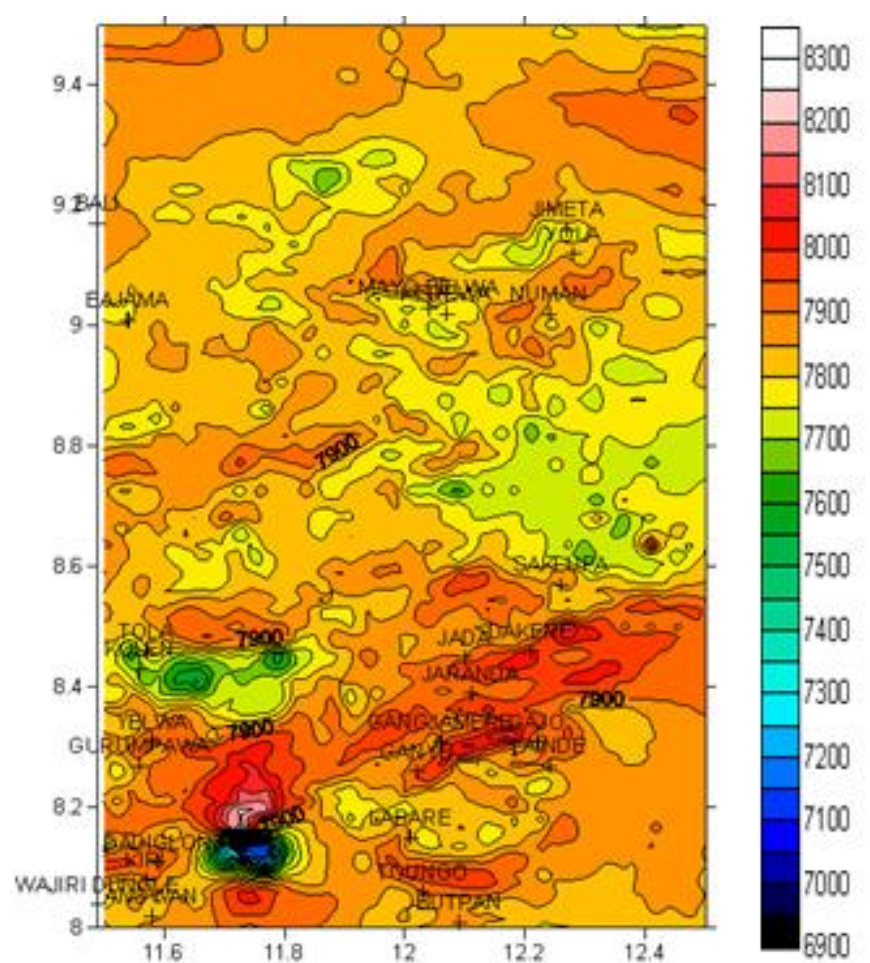

Figure 7: map of study area showing magnetic susceptibility

Figure 7 shows the total field map of the study area. It will be observed that the dominant structural trend is in the NESW direction. The first to fourth degree regional maps (Fig.9) show NE-SW and NW-SE structural trends. The NESW trend could indicate the Charcot fracture zone which is believed to be extending towards the West African region. The first to fourth degree residual (polynomial) maps show small clusters which indicate igneous intrusions, granitic rocks, mineral bodies, rhyolite, granodiorites etc, outcropping at the surface or near the surface. The 3-D surface map of the study area reveals the magnetic basement morphology and relates same with the undulating relief shown. Figure 8 shows the basement depth of the study area. From the map, there are basement highs at the northwest and southeast of the area and a low at the southwest part. The basement area will not be favorable for hydrocarbon prospecting because of the granitic intrusions and low sedimentary piles. It should also be noted that trapped hydrocarbon will be baked as a result of contact metamorphism at the point of intrusion. 
International Journal of Science and Research (IJSR)

ISSN (Online): 2319-7064

Index Copernicus Value (2013): 6.14 | Impact Factor (2014): 5.611

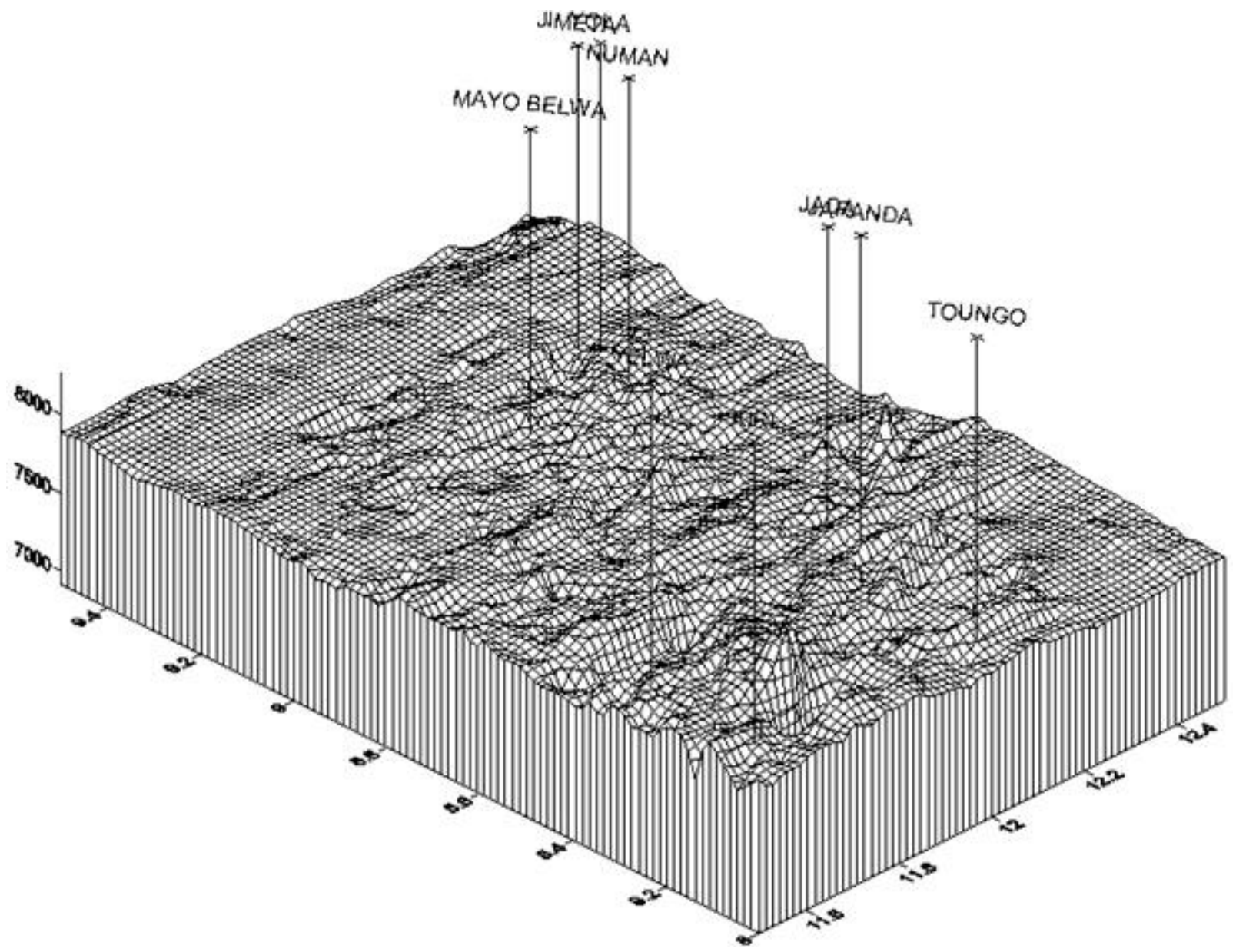

Figure 8: 3-D map showing magnetic basement
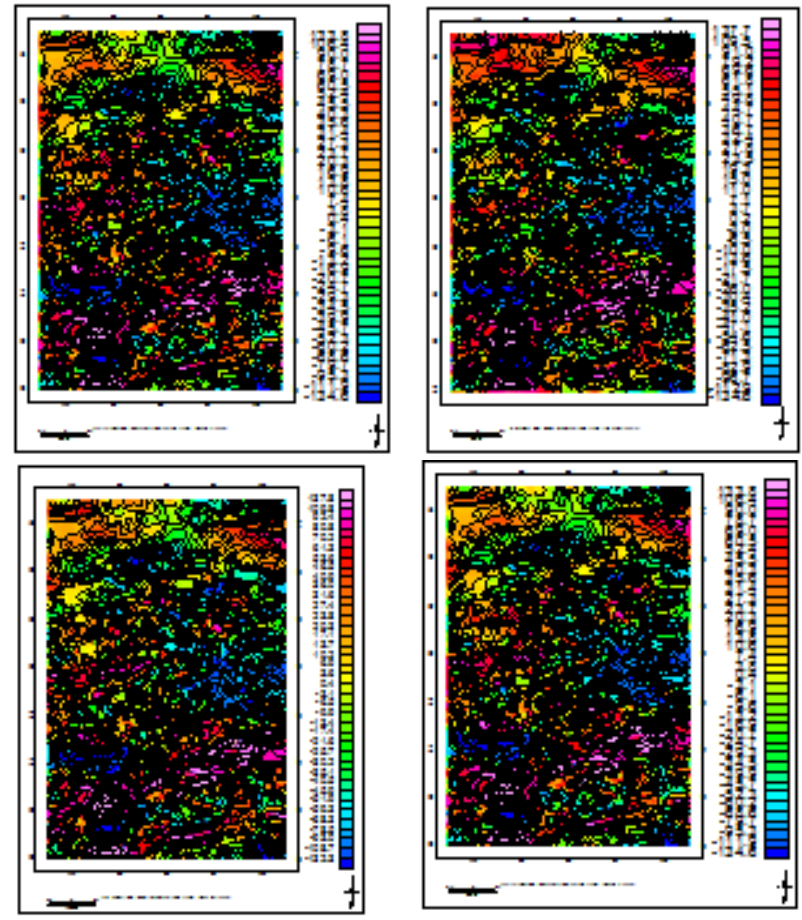

Figure 9: First to forth regional magnetic field 


\section{International Journal of Science and Research (IJSR) ISSN (Online): 2319-7064}

Index Copernicus Value (2013): 6.14 | Impact Factor (2014): 5.611
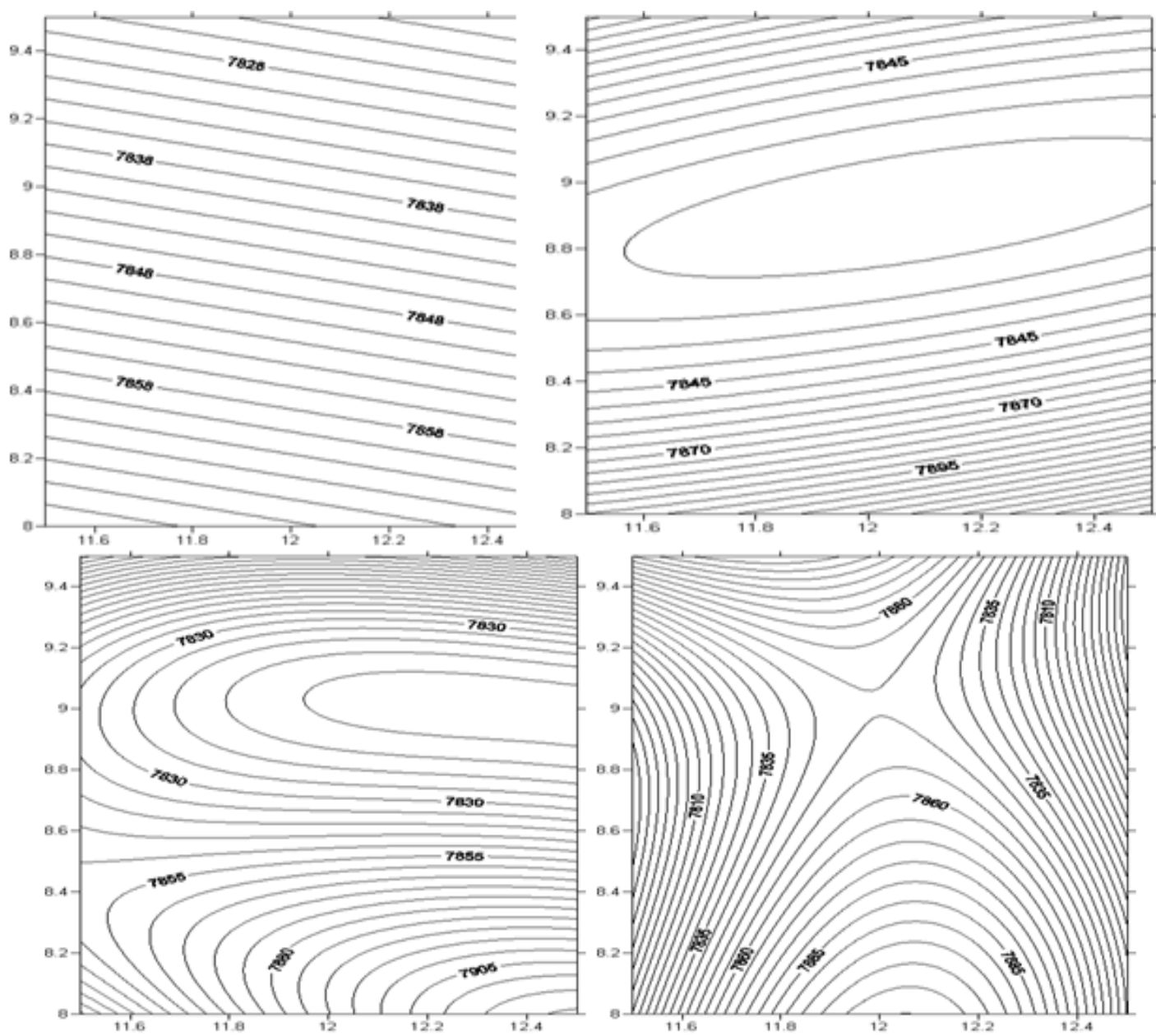

Figure 10: First to forth residual magnetic field

Table 1: Spectral depth estimation

\begin{tabular}{|c|c|c|c|c|c|c|}
\hline Spectral Block & \multicolumn{2}{|c|}{ Longitude } & \multicolumn{2}{c|}{ Latitude } & \multicolumn{2}{c|}{ Depth Km } \\
\hline & $\mathrm{X}_{1}$ & $\mathrm{X}_{1}$ & $\mathrm{Y}_{1}$ & $\mathrm{Y}_{1}$ & $\mathrm{D}_{1}$ & $\mathrm{D}_{2}$ \\
\hline Kiri A & 11.5 & 11.75 & 8 & 8.25 & 0.6 & 1.98 \\
\hline Kiri B & 11.5 & 11.75 & 8.25 & 8.5 & 0.9 & 2.1 \\
\hline Kiri C & 11.75 & 12 & 8 & 8.25 & 0.8 & 1.89 \\
\hline Kiri D & 11.75 & 12 & 8.25 & 8.5 & 0.92 & 2.06 \\
\hline Monkin A & 11.5 & 11.75 & 8.5 & 8.75 & 0.57 & 2.9 \\
\hline Monkin B & 11.5 & 11.75 & 8.75 & 9 & 0.66 & 2.6 \\
\hline Monkin C & 11.75 & 12 & 8.5 & 8.75 & 0.11 & 2.7 \\
\hline Monkin D & 11.75 & 12 & 8.75 & 9 & 0.94 & 2.92 \\
\hline Jada A & 12 & 12.25 & 8 & 8.25 & 0.67 & 2.75 \\
\hline Jada B & 12 & 12.25 & 8.25 & 8.5 & 0.598 & 2.61 \\
\hline Jada C & 12.25 & 12.5 & 8 & 8.25 & -1.174 & 2.67 \\
\hline Jada D & 12.25 & 12.5 & 8.25 & 8.5 & 0.88 & 2.78 \\
\hline Dong A & 11.5 & 11.75 & 9 & 9.25 & 0.35 & 2.52 \\
\hline Dong B & 11.5 & 11.75 & 9.25 & 9.5 & 0.2 & 2.41 \\
\hline Dong C & 11.75 & 12 & 9 & 9.25 & 0.98 & 2.38 \\
\hline Dong D & 11.75 & 12 & 9.25 & 9.5 & 0.67 & 2.255 \\
\hline Toungo A & 12.25 & 12.5 & 8 & 8.25 & 0.54 & 2.06 \\
\hline Toungo B & 12.25 & 12.5 & 8.25 & 8.5 & 0.98 & 2.05 \\
\hline Toungo C & 11.5 & 11.75 & 8 & 8.25 & 0.62 & 1.98 \\
\hline Toungo D & 11.5 & 11.75 & 8.25 & 8.5 & 0.28 & 1.575 \\
\hline Numan A & 12.25 & 12.5 & 9.0 & 9.25 & 0.2 & 2.45 \\
\hline Numan B & 12.25 & 12.5 & 9.25 & 9.5 & 0.9 & 2.39 \\
\hline Numan C & 11.5 & 11.75 & 9.0 & 9.25 & 0.2 & 2.58 \\
\hline Numan D & 11.5 & 11.75 & 9.25 & 9.5 & 0.9 & 2.34 \\
\hline Average Depth & & & & & 0.5539 & 2.3729 \\
\hline
\end{tabular}

The structural trend is predominantly in the NE-SW direction. The drainage pattern is dendritic which is indicative of lithological, structural and topographic differences. It is also indicative of alluvial rocks, which is typical of the geology of the area that consists mainly of sedimentary rocks. Areas with topographic heights averaging about $500 \mathrm{~m}$ are potential region for groundwater assessment. These areas agree with areas in the lineament map where the lineament density is high. It was observed that these regions have a lot of lineaments crossing each other which is indicative of groundwater availability. From the magnetic data analysis, it is observed that the dominant structural trend is in the NE-SW direction which is in agreement with the remote sensing data.

The remote sensing technique is a very useful tool in groundwater assessment, particularly, the mapping of the lineaments. This gives a clear picture of regions where groundwater is available.

\section{Conclusion}

The structural trend is predominantly in the NE-SW direction. The drainage pattern is dendritic which is indicative of lithological, structural and topographic differences. It is also indicative of alluvial rocks, which is typical of the geology of the area that consists mainly of sedimentary rocks. Areas with topographic heights averaging about $500 \mathrm{~m}$ are potential region for groundwater 


\section{International Journal of Science and Research (IJSR) \\ ISSN (Online): 2319-7064}

Index Copernicus Value (2013): 6.14 | Impact Factor (2014): 5.611

assessment. These areas agree with areas in the lineament map where the lineament density is high. It was observed that these regions have a lot of lineaments crossing each other which is indicative of groundwater availability. From the magnetic data analysis, it is observed that the dominant structural trend is in the NE-SW direction which is in agreement with the remote sensing data.

The remote sensing technique is a very useful tool in groundwater assessment, particularly, the mapping of the lineaments. This gives a clear picture of regions where groundwater is available.

\section{References}

[1] Benkhelil, J., (1989). The Origin and Evolution of the Cretaceous Benue Trough (Nigeria). Journal of African Earth Sciences 8, 251-282.

[2] Ghazala, H.H., (1993). Geological and Structural Interpretation of Airborne Surveys and Its Significance for Mineralization, South Eastern Desert, Egypt. Journal of African Earth Sciences, Vol. 16; No. 13; pp. 273285.

[3] Henkel, H. and Guzmann, M. (1997). Magnetic Features of the Fracture Zones. Geo- Exploration, Vol.15; pp.173-181.

[4] Kangoko, R., Ojo, S.B. and Umego, M.N. 1997. Estimation of basement depths in the Middle Cross River Basin by spectral analysis of the aeromagnetic field. Nig. Journ. Of Physics., Vol. 9; pp.30-36.

[5] Olade, M.A. (1975). Evolution of Nigeria's Benue Trough (aulacogen): A tectonic model. Geol. Mag. $112,576-583$

[6] Ofoegbu C, A review of the geology of the Benue Trough of the Nigeria; Journal of African Sciences, Vol.3 pp.285-291, 1985a

[7] bu C, Long Wavelength anomalies and the crustal structure underneath the Benue Trough an surrounding regions, Nig, J, Ming, Geol. 22, 45 - 50, $1985 \mathrm{c}$

[8] Ofoegbu C, A preliminary result of a pseudogravity study of the Benue Trough, Nigeria. J. Afr.EarthSci; 5: 187- 192, 1986.

[9] Grant N, South Atlantic, Benue Trough and Gulf of Guinea Cretaceous triple Junction; Geological Society of American Bulletin 82, pp.2295 - 2298, 1971

[10] Obaje N, Geology and Mineral resources of Nigeria. Springer Dordrecht Heidelbug London New York 10-30, 2004

[11] Olade M, 1975. Evolution of Nigerian Benue trough (Aulocogen): A tectonic model. Geol. Mag. 112 , pp.575 -583 .

[12] Ofoegbu, C. Odigi M, Basement structures and ore mineralization in the Benue Trough, In the Benue Trough: Structure and Evolution (ed.Ofoegbu, C.0,)Earth Evol, Sci, 239-248, 1989.

[13] Cratchley, C. Jones P, An interpretation of Geology and Gravity anomalies of the Benue Valley Nigeria Geophy. Pap.Overseas Geol.Surv.London, No, 1,1965.

[14]Mishra, D. Naidu,P.( 1974).Two-dimentional Power spectral analysis of aeromagnetic fields, Geophysics Prop, 22, $345-534$

[15] Onyewuchi, R. Opara A, Ahiarakwem C,and Oko, :Geological Interpretations Inferred From Airborne Magnetic and Landsat Data: Case Study of Nkalagu Area, Southeastern Nigeria, International Journal of Science and Technology, Volume 2 No.4, 2012.

[16] Samuel, O.Olusola J, Olabisi A: Stratigraphic Evolution and Petroleum Potential of Middle Cretaceous Sediments in the Lower and Middle Benue Trough,Nigeria: Insights from New Source Rock Facie Evaluation, Petroleum Technology Development Journal, Vol. 1, 2011 